Hsiang: China Rising in Latin America

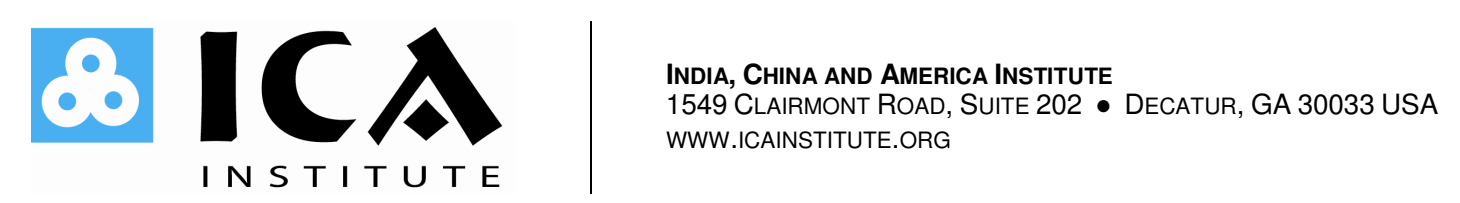

China Rising in Latin America: More Opportunities than Challenges

Antonio C. Hsiang

Journal of Emerging Knowledge on Emerging Markets
Volume 1 Issue 1
November 2009 


\section{China Rising in Latin America: More Opportunities than Challenges}

Journal of Emerging Knowledge on Emerging Markets

Volume 1 Issue 1

November 2009

\section{Introduction}

ccording to Jorge I. Domínguez, professor at Harvard University, there were two
exogenous shocks to established Latin American international relations at the
beginning of the twenty-first century. "The first was the growing distance between the region's governments and the administration of U.S. President George W. Bush over many issues....The second was the dramatic entrance of the People's Republic of China as a significant and, in some instances, political partner." ${ }^{1}$ The geo-strategic implications of this development are broad: China's presence in the region not only has serious impacts on the U.S.'s role in its "backyard," it has consequences for the security situation in the Taiwan Strait.

China's rise in Latin America has been "prompting some to declare the end of the Monroe Doctrine-America's traditional insistence, voiced by President James Monroe in 1823, that any meddling by outsiders in its hemisphere is "dangerous to our peace and safety.",2

1 Jorge Domínguez, "China and Latin America: Shared Gaines," Latin Business Chronicle, May 30, 2006.

2 "The dragon in the backyard," The Economist, Aug. 13, 2009. 
For some, China became the US's new challenger in Latin America. "Almost two centuries later, Monroe's fears are finally coming true, as extra-hemispheric powers such as Russia and China are beginning to foster a new generation of intrusive relations with Latin American nations."

Similarly, for Mary Anastasia O'Grady, columnist of The Wall Street Journal, "China is becoming a political rival of the U.S. in its own backyard." China is also "perceived ...in the US as a growing rival for energy resources, spreading its presence into the Middle East and, more recently, Latin America." General Bantz Cradock, former head of the U.S. Southern Command, warned that China's influence in Latin America is "an emerging dynamic that could not be ignored." Peter Hakim, President of the Inter-American Dialogue, finds "many people in Latin America look to China as an economic and political alternative to U.S. hegemony."7 Hillary Clinton, the secretary of state, has noted that China and Iran are making "disturbing" gains in the region.

However, one of the important reasons for shrinkage of United States hegemony in its "backyard" is because Washington "goes wrong in Latin America through inattention, when it fails to confront emerging problems before they turn into crises." Not only during the Bush administration, but nine months into Obama's administration, "Western Hemisphere Affairs is the only regional bureau in the State Department that does not have an Obama appointee serving as assistant secretary of state and the most influential nation in the region, Brazil, has no U.S. ambassador." 8 On the contrary, many Latin Americans prefer to see China's expanding ties to their region as an opportunity. Even for Washington, "the developing trade between China and Latin American countries represents an opportunityif the U.S. plays its cards right."

During the Bush administration, there seems to be a precipitous decline in good will towards the U.S. from Latin American counterparts. On December 16, 2008, the Group of

\footnotetext{
${ }^{3}$ Adam Kott, "Brazil - Lula's Last Year in Review and Future Expectations," COHA Report, Feb. 23, 2009.

${ }^{4}$ Mary Anastasia O’Grady, “The Middle Kingdom in Latin America,” The Wall Street Journal, Sept. 6, 2004, p. A7.

${ }^{5}$ Guy Dinmore, "US Starts to Accommodate the Emerging Influence of China," The Financial Times, Dec. 23, 2004.

6 Pablo Bachelet, “China's Latin Influence is Growing, General Says,” The Miami Herald, March 10, 2005.

7 Peter Hakim, "Is Washington Losing Latin America?" Foreign Affairs, Vol. 85, No. 1, (Jan./Feb.) 2006, p.46.
}

8 Bernard Aronson, “U.S. must confront neighbors' crises soon,” The Miami Herald, Oct. 11, 2009.

${ }^{9}$ Hugo Restall, “China's Latin Economic Gambit,” The Wall Street Journal, Aug. 23, 2009. 
Rio, a body created in 1986 to promote Latin American cooperation, accepted Cuba as its $23^{\text {rd }}$ member. The conference was held at Costa do Sauipe in Brazil and was attended by dignitaries of 33 Latin American and Caribbean countries. In defiance of U.S. opinion, the Group of Rio welcomed Raúl Castro on his first trip abroad since succeeding Fidel in 2006. So it's not an accident that on the same day, then-President George W. Bush's Secretary of Commerce Carlos Gutiérrez, a fierce anti-Castro Cuban-American, declared the U.S. would not lift the embargo against Cuba.

The 33 Latin American nations attending the summit celebrated what many described as a new era of regional independence from Washington by giving a hero's welcome to Raúl Castro. "No wonder: for anyone who had not already noticed, the summit buried for good the 1823 Monroe Doctrine, which declared Latin America off-limits to European powers."10 In keeping with this development, the Brazilian Foreign Ministry has suggested that Raúl make a gesture of goodwill towards the international community perhaps a gradual but significant political opening including the release of political prisoners. This would help prove Cuba has embarked on a genuine transition.

Nevertheless, the U.S. has not resigned itself to a diminished role in Latin America. For Richard N. Haass, President of Council on Foreign Relations, "countries in the region have not only grown stronger but have expanded relations with others, including China and India. U.S. attention has also focused elsewhere in recent years, particularly on challenges in the Middle East. The result is a region shaping its future far more than it shaped its past." "11 According to Thomas A. Shannon Jr., the U.S. Assistant Secretary of State for the Western Hemisphere, "We may not have been present physically, but we were certainly a major topic of the conversation." Referring to Latin American summit in 2009, he added that "we have chosen to understand these different events as building blocks leading toward a larger summit, which is the [U.S.-backed] Summit of the Americas in April, where we will be present."12

In fact, "Shannon distinguished himself by laboring to repair profoundly damaged relations with Latin America throughout President George W. Bush's time in office. But the damage control came too late in Bush's tenure to salvage matters in an administration that had long since pushed hemispheric concerns off its plate in favor of an obsession with Iraq." 13

\footnotetext{
10 Pepe Escobar, “Obama and the new Latin America,” Asian Times, Dec. 19, 2008.

11 Richard N. Haass, "Foreword," for U.S.-Latin America Relations: A New Direction for A New Reality. Independent Task Force Report No. 60, Council on Foreign Relations, 2008, p.xi.

12 Andrés Oppenheimer, "U.S. is down, but not out, in Latin America," The Miami Herald, Dec. 21, 2008.

13 Natalie Pullen and William Mathis, "Arturo Valenzuela: Looking Back to Look Ahead (I)," COHA, Aug. 25, 2009.
} 
Against the fast changing political and economic backdrop, this paper investigates the reasons for and consequences of China's commitment to pursing the path of peaceful rise and the win-win strategy toward Latin America and the United States.

\section{China: A “Responsible Stakeholder” in Latin America}

China has been rising in Latin America since the twenty-first century for two reasons. "The first is the relative decline in the economic and political pre-eminence of the United States after its brief moment of unchallenged power at the end of the cold war...The second factor is that many Latin American countries have become more self-confident and bent on asserting their diplomatic independence." 14

As the United States' comparative position erodes and China gets more powerful, some realists predict that, "The result of these developments will be tension, distrust, and conflict, the typical features of a power transition." But for G. John Ikenberry, professor at Princeton University, "The rise of China does not have to trigger a wrenching hegemonic transition. The U.S.-Chinese power transition can be very different from those of the past because China faces an international order that is fundamentally different from those that past rising states confronted...Today's Western order, in short, is hard to overturn and easy to join.","15

Similarly, Fareed Zakaria also argues that,

the greater the openness of the global system is, the better the prospects for trade, commerce, contact, pluralism and liberty. Any strategy that is likely to succeed in today's world will be one that has the active support and participation of many countries...there are many good signs in the world today. The most significant rising power-China-does not seem to seek to overturn the established order (as have many newly rising powers in the past) but rather to succeed within it. ${ }^{16}$

There are encouraging signs that the U.S. leadership shares Zakaria's optimism that the interconnectivity of the global system serves a tempering function to China's increasing power. It fact, as early as September 21, 2005, former U.S. Deputy Secretary of State Robert B. Zoellick called on China to act as a "responsible stakeholder" in global affairs. Later, when hosting Chinese President Hu Jintao in Washington in April 2006, former President Bush said, "The United States and China are two nations divided by a vast ocean

14 "The dragon in the backyard," The Economist, Aug. 13, 2009.

${ }^{15}$ G. John Ikenberry, "The Rise of China and the Future of the West," Foreign Affairs, Vol. 87, No. 1 (Jan./Feb.) 2008, pp.23-24.

${ }^{16}$ Fareed Zakaria, “Wanted: A New Grand Strategy,” Newsweek, Dec 8, 2008, p.31. 
- yet connected through a global economy that has created opportunity for both peoples. The United States welcomes the emergence of a China that is peaceful and prosperous, and that supports international institutions." "Since then, China has tried to play the role of a "responsible stakeholder" in global affairs, particularly in Latin America.

On the international level, China's rising levels of wealth and education, improvement of property rights and the establishment of the rule of law greatly contribute to the global political and economic development. For Daniel Deudney and G. John Ikenberry, the fact that autocracies such as China are capitalist

has profound implications for the nature of their international interests that point toward integration and accommodation in the future. The dependence of autocratic capitalist states on foreign trade and investment means that they have a fundamental interest in maintaining an open, rule-based economic system . . . In the case of China, because of its extensive dependence on industrial exports, the WTO may act as a vital bulwark against protectionist tendencies in importing states. ${ }^{18}$

While some argue that a globally-ascending China is a revisionist power seeking important changes in the international system, most agree that China seeks the desired change in a patient, prudent, and peaceful fashion. Americans who deal in foreign affairs especially appreciate the fact that Chinese strategic thinking has moved away from notions of a global class conflict and violent revolution. Instead, today's China emphasizes a "peaceful rising" in global influence while seeking a "harmonious world." Former Secretary of State Zbigniew Brzezinski asserts that the Chinese emphasis on "harmony" can serve as a useful point of departure for U.S.-Chinese relations during the Obama presidency. Thus, "it is a task that President-elect Barack Obama - who is a conciliator at heart - should find congenial, and which President Hu Jintao - who devised the concept of 'a harmonious world'- should welcome. It is a mission worthy of the two countries with the most extraordinary potential for shaping our collective future." 19

In Latin America, China's engagements have been mostly politically neutral. "Despite its disagreements with the United States about many issues, Beijing has adopted a low-key approach and managed to avoid any public confrontation with the United States in the

${ }^{17}$ Carla A. Hills and Dennis C. Blair (chaired), U.S.-China Relations: An Affirmative Agenda, A Responsible Course, Independent Task Force Report No. 59, sponsored by the Council on Foreign Relations, 2007, p.73.

${ }^{18}$ Daniel Deudney and G. John Ikenberry, "'The Myth of Autocratic Revival," Foreign Affairs, Vol. 88, No. 1 (Jan./Feb.) 2009, pp.90.

${ }^{19}$ Zbigniew Brzezinski, "The world benefits if China and US sing in harmony," The Financial Times, Jan. 16, 2009. 
Western Hemisphere." ${ }^{20}$ Nevertheless, China's growing clout is hard to miss. At the APEC summit in 2008, all eyes were on Hu Jintao as he declared that "China now wants to show it is a responsible stakeholder in the region," according to Dan Erikson, a specialist in ChinaLatin American relations from the Inter-American Dialogue. ${ }^{21}$

Compared with Russia's involvement in Latin America, which includes holding joint military exercises with Venezuela and selling arms to the region, China's engagement has been decidedly dovish. Although the neo-conservatives loudly worry about China's close relations with Venezuela, "[the] oil interest actually plays a rather limited role in SinoVenezuelan ties in the foreseeable future."22 This is because while China is obviously keen to enter into oil agreements with Venezuela, Beijing has shown no intention to be drawn into any tensions between Hugo Chavez and the U.S. government.

Despite the fact that the China-Latin America trade still amounts to much less than China's trade with the U.S. (\$560bn) or the EU (\$250bn), recent trends are significant. China's total two-way trade with Latin America shot up from just $\$ 12.2$ billion in 2000 to $\$ 102$ billion in 2007. China is buying more and more Latin American commodities like oil, minerals, and soya. This kind of increase economic integration carries risks: "the danger in the coming years is that fragile Asian economies might look to exclusive trading arrangements or move to protect domestic markets, partly as a result of citizen demands.",23 Consequently, it becomes ever more important that China embraces its role as a responsible stakeholder and avoid the temptations of protectionism and exclusivity.

Some Latin American countries have negatively responded to China's economic penetration. For instance, some Brazilians complain that the Brazil-China trade relation has been unbalanced. Brazil is further frustrated that neither China nor Russia supported its Security Council bid. ${ }^{24}$ However, it is undeniable that China's purchases of commodity greatly contributed to Brazil and Latin America's economic growth in the last decade. China, not the U.S., is now Chile's biggest copper export market; a true New Copper Road, a sea lane rather, now stretches from the southern Pacific to East Asia. China is now Cuba's second-largest trading partner (after Venezuela), with annual bilateral trade at over US\$2.6 billion. China has also pledged $\$ 10$ billion in loans to Brazil's oil giant Petrobras to develop the Western hemisphere's largest oil discovery since 1976. And by 2012, Caracas

\footnotetext{
${ }^{20} \mathrm{He} \mathrm{Li}$, "China's Growing Interest in Latin America and Its Implications," The Journal of Strategic Studies, Vol. 30, No. 4-5 (Aug./Oct.), 2007, p.833.

21 James Painter, “China deepens Latin America ties,” BBC, Nov. 21, 2008.

22 Joseph Y.S. Cheng and Huangao Shi, "Sino-Venezuelan Relations: Beyond Oil," Issues \& Studies, Vol. 44, No. 3 (September), 2008.

${ }^{23}$ Michael Auslin, “America's Future Is Tied to Asia's,” Far East Economic Review, Jan. 21, 2009.

24 "Friends of opportunity," The Economist, Nov 27, 2008, p.47-48
} 
will be selling 1 million barrels of oil a day to Beijing. No wonder Chinese President $\mathrm{Hu}$ Jintao can confidently declare at the APEC summit in Peru that "China and South America have already become extremely good friends and partners. $" 25$

At a signature ceremony in Washington for China's accession into the Inter- American Development Bank (IDB), Zhou Wenzhong, China's Ambassador to the United States, pointed out that "China is the largest developing country, and Latin America is the most important developing region in the world. Bringing these two together for high-level, broadbased and high-quality cooperation is in alignment with the trend of the times and the development needs of the two sides."26 Joining the IDB, China will have additional incentive to fulfill its obligations, strengthen policy coordination with member countries both in and outside the region, engage in IDB's activities, and promote bilateral cooperation in trade financing and infrastructure construction and other areas of mutual concern so as to carry forward poverty reduction and socioeconomic development in Latin America and the Caribbean. And of course, it paves the way for Chinese companies to take part in infrastructure projects in Latin America.

On Nov. 16, 2008, Beijing released China's Policy Paper on Latin America and the Caribbean. It reads, "under new circumstances, the development of relations between China and Latin American and Caribbean countries is faced with new opportunities." China's policy goals on the region include: promoting mutual respect and mutual trust and expanding common ground; deepening cooperation and achieving win-win results; drawing on each other's strengths to boost common progress and intensify exchanges; and confirming that the one China principle is the political basis for the establishment and development of relations between two sides. For Jiang Shixue, expert on Latin American Studies at Chinese Academy of Social Sciences, "cooperation in some fields mentioned in the policy paper is still in its infancy, while opportunities for cooperation in other fields remain unexplored." 27

\footnotetext{
25 Pepe Escobar, “Obama and the new Latin America," Asian Times, Dec. 19, 2008.

26 “China now member of Inter-American Development Bank," Xinhua, Jan. 13, 2009.

${ }^{27}$ Jiang Shixue, "China's first Latin American policy paper is a road map for future relations," Beijing Review (No. 48), Nov. 25, 2008.
} 


\section{All Eyes on China: An Alternative Model for Latin American Economic Development}

\section{The "Beijing Consensus"}

Because "many Latin American countries no longer look to Washington leadership," the socalled Washington Consensus "has lost traction". ${ }^{28}$ As a global rising power, China offers an alternative model for Latin America's development. Even though China has been hurt by the 2008 financial crisis, "its economic and financial powers have been strengthened relative to those of the West. China's global influence will thus increase, and Beijing will be able to undertake political and economic initiatives to increase it further." 29 In fact, "Washington seemed to adopt a Chinese-style solution to its escalating financial problems: greater state intervention to restrict the movement of capital." 30

Thus, Beijing's emergence as a global economic power is seen throughout Latin America as offering an alternative from the Washington Consensus model for economic development. The "Beijing Consensus" is the brainchild of Joshua Cooper Ramo, a former senior editor and foreign editor of Time magazine and later a partner at Kissinger Associates, the consulting firm of former Secretary of State Henry Kissinger. According to Ramo, the Beijing Consensus has three features. The first is a commitment to innovation and constant experimentation in reforms. The second, a rejection of per capita GDP as the only measure of progress, as sustainability and equality also count. And the third, a commitment to selfdetermination. Less developed countries should therefore ensure their own financial integrity and keep great powers in check. ${ }^{31}$

The Beijing Consensus has evolved to describe a plethora of alternative plans for economic development in the underdeveloped world. Ramo argues that China and India, who "most pointedly" ignored the World Bank and the IMF-championed Washington Consensus, "now have records that speak for themselves." 32 Consequently, the so-called the "Beijing Consensus" has been attracting attention in Latin America because of "China's distinctive development model, ... [ [which] posits far more state intervention in the economy and a

\footnotetext{
28 Abraham F. Lowenthal, "The Obama Administration and the Americas: A Promising Start," The Washington Quarterly, Vol. 32, No.3 (July 2009), p. 123-125.

29 Roger C. Altman, "The Great Crash, 2008: A Geopolitical Setback for the West," Foreign Affairs, Vol.88, No. 1 (Jan./Feb.), 2009, p.12.

${ }^{30}$ Harold James, “The Making of a Mess," Foreign Affairs, Vol.88, No. 1 (Jan./Feb.), 2009, p.165.

${ }^{31}$ Ching Cheong, "Rise of the Beijing Consensus?” The Straits Times, Oct. 23, 2008.

32 “Too Much Consensus," Foreign Policy, September/October, 2004, p.17.
} 
greater concern with political stability and strong government to guide the development process." ${ }^{, 33}$

Chinese academics argue that there are three signs that likely predict a convergence between China and Latin America. First, the background conditions are compatible because there are no fundamental conflicts of interest or historical animosities between China and Latin America. Second, the two regions have largely complementary economies. Third, China and Latin America both value diversification in international economic and political relations. For instance, both sides openly oppose "hegemonism," "imperialism," and power monopolies by a few developed countries. ${ }^{34}$

Nevertheless, governmental ideological affinity is only of limited concern in relations between China and Latin America. For example, after establishing diplomatic relations with Chile's Allende government, China did not see any problems with maintaining relations with the subsequent Pinochet regime.

\section{China's Goals in Latin America and its Impacts}

Based on evidence of the events taking place between China and Latin America, "Beijing's goals in Latin America are: counterbalancing American hegemony by enhancing multilateral relations; diversifying external relations to diversify their export strength; and maintaining good relations with major producers of oil (Venezuela), food (Argentina and Brazil) and other raw materials (copper in Chile, nickel and cobalt in Cuba, and pulp in Brazil)." 35

It is no accident that in March 2007, during the Inter-American Development Bank's annual meeting in Guatemala, the Bank's President Luis Alberto Moreno signed an agreement of understanding with Zhou Xiaochuan, the head of the People's Bank of China, to formalize talks over Beijing's request to become a member. In November 2008, China became the third Asian nation to join the bank, after South Korea and Japan. Even former U.S. Treasury Secretary Henry Paulson asserts, "China obviously is a big player, a global economic player, and that's obviously a good thing for Latin America.",36

${ }^{33} \mathrm{He} \mathrm{Li}$, "China's Growing Interest in Latin America and Its Implications," The Journal of Strategic Studies 30, no.4-5 (Aug.-Oct.), 2007, p.848.

${ }^{34}$ Details see the comprehensive report from the China Institute for Contemporary International Relations Latin America Group, "Zhongguo Dui Ladingmeizhou Zhengce Yanjiu Baogao" (Research Report on Chinese Policies Toward Latin America), Xiandai Guoji Guanxi (Contemporary International Relations)(Beijing) No. 4, 2004.

35 Federico J. Tabja, “China and Latin America: Mutual Benefit,” Latin Business Chronicle, Dec. 23, 2008.

${ }^{36}$ Julie Watson, "China seeks to join Latin American bank," The Miami Herald, March 18, 2007. 
$\mathrm{Hu}$ Jintao was famously quoted in 2004 of saying that he expected \$100bn worth of Chinese investment in Latin America in the following 10 years. Although the Chinese government later amended this to mean $\$ 100 \mathrm{bn}$ in bilateral trade, not investment, trade between the two regions eclipsed the $\$ 100 \mathrm{bn}$ mark less than 3 years after Hu's initial pronouncement. As a sign of its long-term intent, China has been negotiating free trade agreements (FTAs) with individual Latin American countries including 1) Chile, the first non-Asian country to sign a FTA with China in 2005; 2) Peru in November 2008; and 3) Costa Rica, under negotiation since January 2009.

World Bank economists report that the rise of China and India is bestowing substantive net benefits on Latin America through higher commodity prices, cheaper industrial inputs, and growing capital inflows. Moreover, if Latin American governments adopt appropriate investment and trade strategies, including negotiating bilateral free-trade agreements, Latin American exporters should be able to successfully penetrate the burgeoning Asian commercial markets and better integrate themselves into Asian-linked global production networks. No wonder economists from the Organization for Economic Cooperation and Development (OECD), generally concur with their World Bank counterparts that "as seen through the Latin American lens, China is closer to heaven than hell.",37

"A closer look at three common perceptions of China's impact on emerging markets can help clarify whether or not Latin American countries can benefit from the ongoing shifting power equation in the world economy." Myth I: The main source of China's competitive advantage is cheap labor. Reality: Low labor costs in China are significant but the wide availability of capital, coupled with very high productivity growth levels, are equally important in explaining China's hard-to-beat competitiveness. Myth II: China has a negative impact on FDI flows to other emerging markets. Reality: Most Latin American economies do not compete for the same type of FDI that China receives and China's investments in Latin America are only the beginning of a trend that offers many opportunities for the region. Myth III: China's rise benefits commodity exporting countries and adversely affects light- manufacturing exporting nations. Reality: China's rise offers opportunities in keeping and sustaining a manufacturing sector. ${ }^{38}$

The fact is that "China and India's growth has not been a zero-sum game for LAC [Latin American and Caribbean], but the potential benefits are not being fully realized. It is crucial that LAC countries take advantage of the growing presence of China and India in world markets by adopting offensive strategies that facilitate both the participation of LAC firms in global production networks and their commercial presence in the two Asian economies'

${ }^{37}$ Richard Feinberg, Book Review on Angel or Devil? China's Trade Impact on Latin American Emerging Markets, Foreign Affairs, (Jan./Feb.) 2007.

38 Ángel Alonso Arroba, Rolando Avendaño, and Julio Estrada, Adapting to the Rise of China: How Can Latin American Companies Succeed? World Economic Forum and OECD Development Center, 2008, p.9-11. 
markets. ${ }^{\circ 9}$ Since formally becoming a member of the Inter-American Development Bank in 2009, China has already contributed $\$ 350$ million to sustain regional development.

Comparisons of export structure are based on the assumption that similar export structures will suggest the highest potential for competition. ${ }^{40}$ An OECD study found: "In general terms .... there is no trade competition between China and Latin America. ... . [Moreover] this trade competition is even decreasing rather than increasing over the recent period of time. Not surprisingly, countries that export mainly commodities face lower competition ... Paraguay, Venezuela, Bolivia and Panama are those exhibiting the lowest figures among 34 selected economies, i.e. those are the countries that suffer less from Chinese trade competition. Brazil could be considered as an intermediate case between Mexico and Venezuela." 41

Facing China's new role in the Western Hemisphere, Latin American government[s] need to boost general competitiveness by lowering country-cost factors and emphasizing policies that promote innovation that favor the companies of tomorrow. Investment in infrastructure that maximizes export comparative advantages and facilitates deeper and faster regional trade and business integration should be a priority, together with funding and support of education and research institutions assimilating the needs and demands of the markets. ${ }^{42}$

For most of Latin America, with the main exceptions of Mexico and Central America, China has been an engine for export growth, allowing exporters to diversify away from traditional markets in the north. Beyond the fact that the region's exports to China are concentrated on commodity products, the issue remains that China's economic and political rise should be a wake-up call for more reforms in the region. ${ }^{43}$

39 Guillermo Perry, Latin America and the Caribbean's Response to the Growth of China and India: Overview of Research findings and Policy Implications, World Bank, 2006, p1.

40 Kevin P. Gallagher and Roberto Porzecanski, "China Matters: China's Economic Impact in Latin America," Latin American Research Review, Vol. 43, No. 1, 2008, p.193.

41 Jorge Blázquez-Lidoy, Javier Rodríguez, and Javier Santiso, “Angel or Devil? China's Trade Impact on Latin American Countries,” OECD Working Paper No. 252, 2006.

42 Ángel Alonso Arroba, Rolando Avendaño, and Julio Estrada, Adapting to the Rise of China: How Can Latin American Companies Succeed? World Economic Forum and OECD Development Center, 2008, p.21.

${ }^{43}$ Ibid., p. 5. 


\section{Latin America as Proving Ground for a "Diplomatic Truce" Between China and Taiwan}

From 2000 to 2008, Latin America had been a diplomatic battlefield between China and Taiwan. During the eight years of his tenure, Taiwan's president Chen Shui-bian pursu[ed] identity politics - at the heavy cost of international isolation, inflamed cross-Strait tensions and economic stagnation. His tactics were often unnecessarily provocative, ranging from calling for independence to renaming public buildings to emphasize Taiwanese identity. Taiwan-U.S. relations are, as a result, at their lowest ebb in decades. ${ }^{44}$

In his final gambit, Chen insisted on holding a national referendum on whether the island should seek to join the United Nations under the name of Taiwan instead of its legal name, the Republic of China. Of course the Security Council, where China has a veto, would never have accepted Taiwan's application. ${ }^{45}$

In March 2008, Taiwan's voters rejected the referendum by a substantial margin and produced a government more favorable to the security across the Taiwan Strait. The mandate of president Ma Ying-jeou is founded on his promise to deliver tangible benefits from better relations with Beijing, including direct airline flights, an economic accord protecting investments, more tourist visits by mainlanders to Taiwan and a peace accord under which China would withdraw the thousands of missiles it aims across the strait. ${ }^{46}$

According to U.S. National Intelligence Director Dennis Blair, a retired admiral who heads 16 U.S. intelligence agencies, the United States must continue to "make sure that military adventures are unattractive" to both sides of the Taiwan Strait. He also cautioned that Taiwan has to realize that its long-term security lies in some sort of an arrangement with China. It does not lie in military defenses.

But Taiwan has long held justifiable complaint about its international political isolation and about Beijing's efforts to force nations to choose diplomatic relations with either Taiwan or China. The Taiwanese fear that if China's policy prevails and renders them completely isolated, Beijing would face minimal international opposition to increased hegemony over the island and, ultimately, to Taiwan's unwilling absorption into the mainland. ${ }^{47}$ Therefore, according to Chong-Pin Lin, president of the Foundation for International and Cross-Strait Studies and Taiwan's former Deputy Minister of National Defense, "Beijing needs to think

\footnotetext{
44 "After Chen," The Wall Street Journal, March 20, 2008.

45 “Cross-Strait Opening," The New York Times (editorial), March 26, 2008.

46 "Test in Taiwan," The Washington Post (editorial), March 25, 2008, p.A14.

${ }^{47}$ John R. Bolton, “What's good for Taiwan," Los Angeles Times, March 29, 2008.
} 
creatively about how to gradually allow Taiwan international space. This is a crucial subject and necessary to win the hearts and minds of Taiwanese people."48

Proposed by President Ma Ying-jeou, the policies of "diplomatic truce" and "modus vivendi" diplomacy have successfully improved cross-strait relations. China also deserves some credit for sharing some international space with Taiwan. In November 2008, APEC issued a list of countries and leaders on which Taiwan was referred to as "Chinese Taipei" and Ma was listed with his official title and photo. "This was the first time that the country's president was introduced in an APEC document and it shows that we have adopted the right strategies of no unification, no independence and no use of force," according to President Ma. ${ }^{49}$

In addition, Lien Chan, Taiwan's former vice-President, was able to attend the APEC meeting in Peru. This is significant because, while the one China principle has long been the political basis for the establishment and development of relations between China and Latin American and Caribbean countries and regional organizations, Lien's participation suggests that Beijing currently has less interest to "isolate" Taiwan in Latin America.

On the last day of 2008, President Hu Jintao offered six proposals to promote peaceful development of cross-strait relationships in a speech to commemorate the 30th anniversary of the mainland's "Message to Compatriots in Taiwan." The six points Hu announced included: 1) an end to political confrontation under the "one China" principle, 2) economic cooperation, 3) promotion of Chinese culture, 4) intensified personal exchange with the Democratic Progressive Party, 5) adequate arrangement for Taiwan to participate in international organizations, and 6) a peace accord.

According to The United Daily News, one of the biggest newspapers in Taiwan, the six proposals put forward by Hu Jintao on the cross-straits relationship are "positive" and "explicit." In fact, most Taiwanese hold positive opinions about the six proposals and see goodwill and understanding in them. More importantly, Hu's remarks signal "that Taiwan's aspiration for participation in international activities, or 'greater international space' in Taiwan's parlance, could be realized through cross-trait negotiations."

Until Ma was elected as Taiwan's president in March 2008, Taipei and Beijing had frequently accused each other of using "checkbook diplomacy" to lure the other's allies in a long-running battle for diplomatic supremacy on the world stage. This battle was particularly fierce in Latin America and seemed like a lose-lose proposition for both China and Taiwan. As He Li correctly points out, "in the long run, China is more likely to

${ }^{48}$ Chong-Pin Lin, “More Carrot Than Stick: Beijing's Emerging Taiwan Policy," China Security, Vol. 4, No. 1 (Winter) 2008, p.13.

${ }^{49}$ Jenny W. Hsu and Mo Yan-chih, "APEC refers to Ma as president," Taipei Times, Nov. 16, 2008, p.3.

50 "Springtime in cross-strait ties," The China Post (editorial), Jan. 3, 2009. 
leverage its economic clout in the region to support its political preference, pressing countries to fall in line on its top foreign policy priority: its claims over Taiwan." ${ }^{, 51}$ But Beijing also understands well that China's prospective success at sweeping Taiwan out from Latin America may force its hand from a de facto to a de jure independence.

Since Ma Ying-jeou took office, relations across the Taiwan Strait have been tremendously improved. Some potential candidates looking to switch their diplomatic recognition from Taipei to Beijing, such as Paraguay and Nicaragua, have been disappointed because China seems more concerned about sustaining "harmonious" relations with Taiwan. In return, President Ma has carefully responded to Beijing's goodwill. He told the New York Times, "we are not dissatisfied with the fact they did not mention Taiwan," referring to Hillary Clinton's trip to Beijing. All eyes are now on Latin America to see whether the "diplomatic truce" between China and Taiwan can be sustained. ${ }^{52}$

\section{Conclusion}

Latin America is now a key region for Chinese foreign policy. However, China has maintained a low profile and avoided antagonizing the United States in the region. It is exaggerated to accuse Beijing of challenging Washington's "Monroe Doctrine" for three main reasons. First, both sides find the trade relationship to be largely beneficial. Thus, the relation between China and Latin America is characterized far more by expanding trade flows and business connections than by establishing traditional military or political ties. Such an approach would further allow China to side-step Washington's Monroe Doctrine by pro-actively diffusing any allegations of a Chinese challenge to Washington's traditional sphere of influence. China supports its trade-oriented goals by behaving as a "responsible stake-holder" in Latin America. Compare with Russia's "security and military-technical cooperation" with Latin American countries, China's engagements, from sending peacekeeping force to Haiti to donating aid to Cuba, have been far more constructive. China's purchase of regional commodities has also been the main factor for Latin America's economic growth in the last decade. In sum, "the expansion of China ... seems to be pulling and crowding in growth in the Latin American region."

Second, China stands to gain tremendous international prestige by offering an attractive alternative model for Latin American economic development. Beijing's emergence means that the Washington Consensus is possibly on the wane. As China formally became a

\footnotetext{
${ }^{51} \mathrm{He} \mathrm{Li}$, “China's Growing Interest in Latin America and Its Implications," The Journal of Strategic Studies 30, no.4-5 (Aug.-Oct.), 2007, p.859.

52 Keith Bradsher, “Taiwan's Low Profile May Aid Its Goals,” The New York Times, Feb. 13, 2009.

53 Daniel Lederman, Marcelo Olarreaga, and Guillermo E. Perry, eds, China's and India's Challenge to Latin America: Opportunity or Threat? Washington, DC: The World Bank, 2009, p. xxii.
} 
member of Inter-American Development Bank in 2009, Beijing now can contribute more to Latin America's development and thus aid global recovery.

Third, Latin American is now the proving ground for a "diplomatic truce" between China and Taiwan. Responding to President Ma Ying-jeou's diplomacy of "modus vivendi," Beijing allowed Lien Chan, Taiwan's former vice-President, to attend the APEC 2008 in Peru. So long as the "one China" principle remains the political basis for Beijing's relations with Latin American and Caribbean countries. China is content to share some of the spotlight with Taiwan, while reaping the multitudinous benefits of improved relationships. The benefits extend beyond China and Taiwan, as the more stable the political relation between Beijing and Taipei, the more economic opportunity will be afforded Latin America and the United States. 